\title{
Oak (Acorn)-Weevil Interactions across an Extensive Latitudinal Gradient in Eastern North America
}

\author{
Michael A. Steele ${ }^{1, * \mathbb{D}}$, Harmony J. Dalgleish ${ }^{2}$, Shealyn Marino ${ }^{1}$, Andrew W. Bartlow ${ }^{1,3} \mathbb{( D}$, Rachel Curtis ${ }^{1,4} \mathbb{D}^{\mathbb{D}}$ and \\ Jeffrey A. Stratford ${ }^{1}$ (D) \\ 1 Department of Biology, Wilkes University, Wilkes-Barre, PA 18766, USA; shealyn.marino@wilkes.edu (S.M.); \\ abartlow@lanl.gov (A.W.B.); rachel.curtis.1005@gmail.com (R.C.); jeffrey.stratford@wilkes.edu (J.A.S.) \\ 2 Department of Biology, The College William \& Mary, Williamsburg, VA 23187, USA; hjdalgleish@wm.edu \\ 3 Los Alamos National Laboratory, Biosecurity and Public Health, Los Alamos, NM 87545, USA \\ 4 Department of Veterinary Integrative Biosciences, Texas A\&M University, College Station, TX 77843, USA \\ * Correspondence: michael.steele@wilkes.edu
}

Citation: Steele, M.A.; Dalgleish, H.J.; Marino, S.; Bartlow, A.W.; Curtis, R.; Stratford, J.A. Oak (Acorn)-Weevil Interactions across an Extensive Latitudinal Gradient in Eastern North America. Diversity 2021, 13, 303 https://doi.org/10.3390/d13070303

Academic Editor: Michael Wink

Received: 28 May 2021

Accepted: 28 June 2021

Published: 5 July 2021

Publisher's Note: MDPI stays neutral with regard to jurisdictional claims in published maps and institutional affiliations.

Copyright: (C) 2021 by the authors. Licensee MDPI, Basel, Switzerland. This article is an open access article distributed under the terms and conditions of the Creative Commons Attribution (CC BY) license (https:// creativecommons.org/licenses/by/ $4.0 /)$

\begin{abstract}
Recent studies have explored how nut weevils (Curculio and Conotrachelus spp. (Coleoptera: Curculionidae) prey on the fruits (acorns) of oak (Quercus spp.). However, few, if any, have examined these interactions over both an extensive geographic area and over several years. Here, we observed patterns of infestation in acorns of both red oak (Quercus rubra) and white oak (Quercus alba) over an eight-year period along a latitudinal transect, extending as far as $900 \mathrm{~km}$, across much of the shared range of these two oak species. Although weevil prevalence did not differ significantly between the two oak species, in red oak, infestation prevalence increased significantly with latitude. In contrast, an opposite pattern was evident in white oak, with the highest infestation prevalence occurring at lower latitudes. One controlled measure of cotyledon damage was significantly lower in acorns of red oak than those of white oak, which may in part be due to larger acorn size at the lower latitudes. Future investigations in this system should focus on the distribution of weevil species (with DNA barcoding) across this range and geographic variation in chemical gradients that likely determine patterns of weevil damage in individual acorns.
\end{abstract}

Keywords: Quercus alba; Quercus rubra; acorns; Curculio; latitudinal variation in insect infestation

\section{Introduction}

The oaks (genus Quercus), which includes 350-500 species worldwide, are distributed widely across the globe from northwestern South America, through Central America, North America including Mexico, Europe, the northwestern edge of Africa, and much of eastern Asia [1-4]. Across this range, the fruits (acorns) of oak are regularly preyed on by the larvae of several insect seed predators, especially the nut weevils (Curculio and Conotrachelus spp. (Coleoptera: Curculionidae)), and at a significantly lower frequency, other insects such as the filbertworm moth (Cydia spp. (Lepidoptera: Tortricidae)) acorn moth (Valentina spp. (Lepidoptera: Blastobasidae)) and midge larvae (Diptera), the vast majority of which are predispersal seed predators. Adults of these species deposit their eggs in maturing acorns where they develop into larvae and then feed on the cotyledon prior to exiting acorns just before or soon after seed fall.

Numerous studies have shown how various environmental factors influence larval infestation, survival and growth, and life history characteristics especially in Curculio species, clearly the most abundant and widespread insect predator of oak acorns. Examples of such investigations include studies on the effects of annual acorn abundance and seed size of Curculio infestation (e.g., [4-6]), shifts in autumn seed drop of oaks in response to Curculio infestation [7,8], long-term patterns of Curculio infestation in oaks [9], the diversity of Curculionidae that occur in oaks [10] the effects of acorn satiation on life history traits and morphology of Curculio [11], the effects of both oak masting patterns and acorn size 
on patterns of satiation in Curculio [6,12-14], the effects of nitrogen deposition on patterns of weevil infestation and seed mortality [15], the impact of vertebrate seed predators on Curculio-infested acorns and weevil mortality (e.g., $[8,16])$, and the specific acorn characteristics (e.g., chemical gradients and germination strategies) tied to acorn tolerance of Curculio damage $[4,17,18]$.

Despite this extensive diversity of studies on oak-Curculio interactions, relatively few have examined geographic variation in patterns of weevil infestation and the likely implications of such. An understanding of the latitudinal variation in patterns of infestation is essential for assessing the impact of an important seed predator that may limit acorn survival and establishment across an oak's range. To ensure the most reliable measures of such latitudinal variation, we conducted our study over repeated years.

One recent study by Bonal et al. [19] relied on DNA analyses of Curculio samples across an $800 \mathrm{~km}$ latitudinal transect in California oaks and found no cryptic species of Curculio but only sister species that did not segregate across Quercus species. Genetic differentiation increased with distance regardless of species. In another similar study, Bogdziewiez et al. [6] examined patterns of weevil infestation in 29 populations of holm oak (Quercus ilex) across a latitudinal gradient in the Iberian Peninsula and showed that infested acorns in the north were predominantly infested with a smaller weevil, C. glandium, and those in the south more often infested with a larger weevil, C. elephas. However, the larger acorn size in the south (as much as four times larger than in the north) allowed southern populations of $Q$. ilex to potentially tolerate damage to weevils despite the larger species of seed predator found there.

Here, we investigated biogeographic variation in weevil infestation in two species of oak (Q. alba, the white oak, and Q. rubra, the northern red oak), with nearly identical overlapping ranges, along a similar latitudinal gradient each year for eight years. These two oak species share overlapping and nearly identical distributions in the eastern U.S as two dominant species in eastern deciduous forests. Overall in this study we sought to determine how patterns of infestation varied geographically between these two species and in relation to variation of individual acorn characteristics. Our goal was to address three questions: (1) how patterns of infestation vary across latitude in each of these two species, (2) if and how patterns of infestation differ between the two species, and (3) if patterns of infestation in individual acorns of each species of oak vary with acorn morphology, size, and latitude, potentially providing tolerance of infestation as suggested by Bogdziewicz et al. [6].

\section{Materials and Methods}

In the autumn of each year of 2011 to 2019 (excluding 2018), we sampled acorns beneath mature trees of both $Q$. alba and Q. rubra along a latitudinal gradient from as far north as Colchester, Vermont $\left(44^{\circ} 50^{\prime} 25^{\prime \prime}\right.$ lat., $-73^{\circ} 19^{\prime} 44^{\prime \prime}$ long.) and as far south as Fairplay, South Carolina ( $34^{\circ} 49^{\prime} 67^{\prime \prime}$ lat., $-83^{\circ} 02^{\prime} 06^{\prime \prime}$ long.). In most years, transects extended from northern New York to North Carolina, and included as far north as Vermont and as far south as Georgia in some years (Figure 1). Collections were primarily from along Interstate 81 South and Interstate $95 \mathrm{~N}$ corridors. Sampling was usually completed within 5 to 7 days between Oct 7th and 20th, during which time we sampled acorns from the ground beneath the canopies of both oak species. We specifically standardized our collection time in this way to minimize variation in acorn maturation, infestation and seed drop for an individual oak species (see [20]). We sampled acorns from adult Q. alba and Q. rubra trees and other oaks as well although we only focus on Q. alba and Q. rubra because of the limited geographic distribution and density of other species along this transect. 


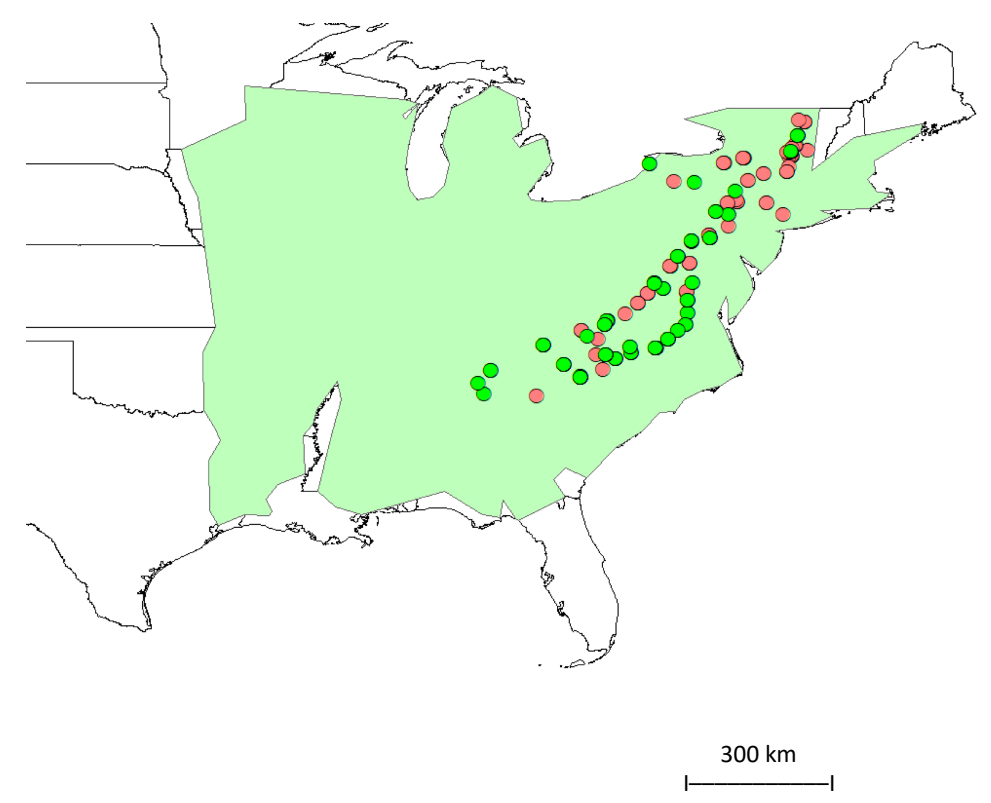

Figure 1. Map of collection sites, showing those where acorns of red oak (Q. rubra, red dots) and white oak (Q. alba, green dots) were sampled. Efforts were made to collect from the same trees each year between 2011 and 2019 (excluding 2018), but in many years, oaks failed to produce acorns. Green shaded area is the approximate distribution of Q. alba in U.S. Q. rubra is distributed over approximately $95 \%$ of the same area except in some areas of the far southeast and southwest of Q. alba distribution.

We chose rest stops along major highways for several reasons, including accessibility of open oak stands, and the greater probability of heavier acorn crops in these open stands. Recent research also suggests that in oaks, masting and natural patterns of predator satiation of insect seed predators may be more important where oaks dominate their communities, and that masting is less frequent and less intense in diverse, more dense forests [21]. Thus, only sites where oaks dominated were chosen for the study. This generally prevented sampling isolated populations of Curculio which can occur due to limited dispersal ability of the genus.

At each stop, we first searched the entire site for evidence of acorn production; we then hand mapped all trees producing acorns relative to other trees and buildings/roads at that specific stop so that we could locate them easily in future years. New oak trees (i.e., those producing acorns for the first time in our survey) were identified and given a catalogue number; we then noted immediate surroundings and recorded GPS coordinates, diameter at breast height (DBH), and approximate height. Acorns were collected from directly beneath the canopy of the tree. To do this, acorns were raked into piles (or collected by hand) making sure that acorns were sampled from several pseudo-random parts of the canopy but excluding those areas that could be mixed with acorns from neighboring trees. Whenever possible, samples of 100 acorns were bagged per tree with a damp paper towel placed in each bag. Following collection surveys, all acorns were returned to Wilkes University (Wilkes-Barre, PA, USA), and placed in cold storage at $4{ }^{\circ} \mathrm{C}$ where they remained until measured and inspected for weevils.

Acorn samples ranged from 50 to 100 acorns per tree with smaller acorn numbers occurring in years of low acorn production. Within approximately 1-2 months of collection (sometimes a few weeks longer in years of larger acorn samples), acorns were removed from cold storage and systematically evaluated for insect damage by Curculio and other insects. The presence of larvae of Cydia, Valentina and dipterans occurred at low frequency and were recorded but were not included in these analyses. Based on these surveys from 2011 to 2019 (excluding 2018) a total of 16,562 acorns (8120 Q. rubra and 8442 Q. alba, Table 1) were measured and sampled for Curculio larvae. 


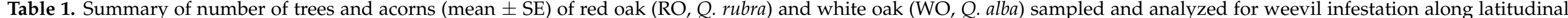
gradients over an eight-year period. Additionally, shown are the northern- and southern-most latitudes (and nearest major city) for each year of sampling.

\begin{tabular}{|c|c|c|c|c|c|c|c|c|c|c|}
\hline \multirow{2}{*}{ Year } & \multirow{2}{*}{$\begin{array}{l}\text { No. Q. rubra } \\
\text { Trees }\end{array}$} & \multirow{2}{*}{$\begin{array}{c}\text { Mean } Q . \text { rubra } \\
\text { Acorns per } \\
\text { Tree }\end{array}$} & \multirow{2}{*}{$\mathrm{SE}(+/-)$} & \multirow{2}{*}{$\begin{array}{l}\text { No. Q. alba } \\
\text { Trees }\end{array}$} & \multirow{2}{*}{$\begin{array}{l}\text { Mean Q. alba } \\
\text { Acorns per } \\
\text { Tree }\end{array}$} & \multirow{2}{*}{$\mathrm{SE}(+/-)$} & \multicolumn{2}{|c|}{ Northern Most } & \multicolumn{2}{|c|}{ Southern Most } \\
\hline & & & & & & & City & Latitude & City & Latitude \\
\hline 2011 & 34 & 15.53 & 2.69 & 17 & 9.47 & 1.6 & Syracuse, NY & $43^{\circ} 1^{\prime} 55^{\prime \prime}$ & Williamsburg, NC & $35^{\circ} 58^{\prime} 35^{\prime \prime}$ \\
\hline 2012 & 18 & 54 & 4.25 & 22 & 49.36 & 2.74 & Clarkstown, NY & $41^{\circ} 7^{\prime} 51^{\prime \prime}$ & Kings Mountain, NC & $35^{\circ} 10^{\prime} 0.8^{\prime \prime}$ \\
\hline 2014 & 31 & 55.61 & 2.13 & 35 & 51.14 & 2.28 & Queensbury, NY & $43^{\circ} 16^{\prime} 1^{\prime \prime}$ & Calhoun, GA & $34^{\circ} 33^{\prime} 0.7^{\prime \prime}$ \\
\hline 2015 & 23 & 47.13 & 3.72 & 16 & 41.06 & 4.29 & Lake Champlain, NY & $44^{\circ} 35^{\prime} 2^{\prime \prime}$ & West Marion, NC & $35^{\circ} 38^{\prime} 20^{\prime \prime}$ \\
\hline 2016 & 18 & 37.17 & 1.66 & 21 & 36.9 & 2.41 & Mountain Top, PA & $41^{\circ} 7^{\prime} 49^{\prime \prime}$ & West Marion, NC & $35^{\circ} 38^{\prime} 17^{\prime \prime}$ \\
\hline 2019 & 25 & 32.2 & 1.22 & 22 & 29.64 & 1.04 & Hershey, PA & $40^{\circ} 17^{\prime} 7^{\prime \prime}$ & Athens, TN & $35^{\circ} 25^{\prime} 0.8^{\prime \prime}$ \\
\hline
\end{tabular}


First, the mass $(0.1 \mathrm{~g})$, length $(0.1 \mathrm{~mm})$ width $(0.1 \mathrm{~mm})$ and diameter of the basal scar $(0.1 \mathrm{~mm})$ of each acorn were determined. Each acorn was inspected for exit holes, with each hole $>3 \mathrm{~mm}$ in diameter in the acorn pericarp assumed to be that of one Curculio larvae (note that other insect larvae will make smaller holes and occasionally Curculio and other insect larvae may exit from existing Curculio holes, but given the low frequency of these events, we considered these occurrences negligible). Previous studies suggest that cotyledon chemistry $[17,22]$ and possibly greater pericarp thickness closer to the embryo [13] direct both vertebrate and insect seed predators toward the basal end of the acorn, opposite the embryo (seed) thereby increasing survival of partially damaged acorns $[4,17]$. We therefore determined the number of weevil larvae and exit holes in the basal and apical ends of each acorn.

Each acorn was cut in half to produce a basal and apical half. We carefully removed the cotyledon so the pericarp thickness $(0.1 \mathrm{~mm})$ could be determined. The cotyledon was then diced carefully to inspect for evidence of infestation by Curculio and all other insect larvae. Intact weevil larvae were stored in $99 \%$ ethanol in a -20 freezer for subsequent DNA barcoding and species identification. Acorn cotyledon was also inspected and the $\%$ insect or fungal damage estimated. A composite sample of cotyledon from $\geq 5$ acorns were quick frozen with liquid nitrogen and dried in a freeze dryer at $50{ }^{\circ} \mathrm{C}$. At the time of this publication, lead authors are developing a systematic procedure for identifying Curculio species across this gradient.

Infestation prevalence was calculated as the number of acorns per tree infested by one or more weevils divided by the total number of acorns sampled for that tree. We used a Wilcoxon test to compare the overall prevalence between Q. rubra and Q. alba. A visual inspection of data revealed considerable heteroscedasticity in prevalence and its relation to latitude for both species. Therefore, we used quantile regression ( $\mathrm{R}$ package quantreg, version 5.85 https: / CRAN.R-project.org/package=quantreg, accessed on 12 December 2020) and modelled the median, and the 97.5th and 2.5th percentiles. This approach quantifies how variation in prevalence changes along latitude and tests for an overall trend. We analyzed the effects of latitude on seed size using a linear model and a linear mixed model using function glmer in the R package lme4 [23] with tree as a random effect and latitude as a fixed effect. We also tested for an overall difference in prevalence between northern and southern trees in each species by running Wilcoxon tests. For this test we used $39^{\circ} \mathrm{N}$ to divide northern and southern trees.

For acorns infested with one or more weevils, we tested the difference in the number of weevils in the basal end of the acorn versus the apical end with a Wilcoxon test. We used the function glmer in the R package lme4 [23] to examine if the number of weevils in the basal end varied with latitude. For this test we used the difference between the number of weevils in the basal and apical end as the response variable, individual tree as the random variable, and latitude as the fixed variable.

We analyzed damage to acorn cotyledon between oak species across latitude. To control for weevil development and number of weevils in an acorn, we chose a subset of acorns with only one exit hole and no other weevils present. Estimates of $>50 \%$ cotyledon remaining were considered viable acorns likely to germinate and establish. This was based on previous experimental results showing that acorns of six species, including $Q$. rubra and $Q$. alba, were able to sustain significant cotyledon damage and still germinate and establish [14]. In that study, it was shown that acorns with $<50 \%$ cotyledon removed were often able to survive, germinate and develop into seedlings. We therefore converted the percentage of remaining cotyledon into a dummy binary variable that represented $>50 \%$ (viable seeds) or $<50 \%$ (nonviable seeds) of the cotyledon remaining. We used the $\mathrm{R}$ package glmer to run a binomial regression with latitude as the fixed effect and individual tree as the random effect to compare damage rates across latitude. We examined the possible interaction between year and latitude by treating year as a fixed effect in a generalized linear model with normal errors. We also plotted prevalence across latitude for 
each year to allow for visual inspection for within year trends. All graphics and analyses were conducted in R 4.0.1 [24].

\section{Results}

\subsection{Weevil Prevalence across Years and Latitudinal Gradient}

For Q. rubra, latitude had no significant effect on the median $(p=0.53)$ and 2.5th percentile $(p=1.0)$ of weevil prevalence. However, the 97.5th percentile of prevalence significantly increased with latitude in $Q$. rubra $(\beta=0.045, p<0.001$, Figure $2 \mathrm{~A})$. In contrast, for $Q$. alba, both the median ( $\beta=-0.021, p=0.011$, Figure $2 B$ ) and the 97.5th percentile ( $\beta=-0.043, p<0.001)$ decreased with latitude. Latitude did not have a significant effect on the 2.5th percentile in $Q$. alba $(p=0.6)$. There was no significant difference between Q. rubra and Q. alba in weevil prevalence when not accounting for latitude ( $\mathrm{W}=15644$, $p$-value $=0.155$, Figure 3).

(A)

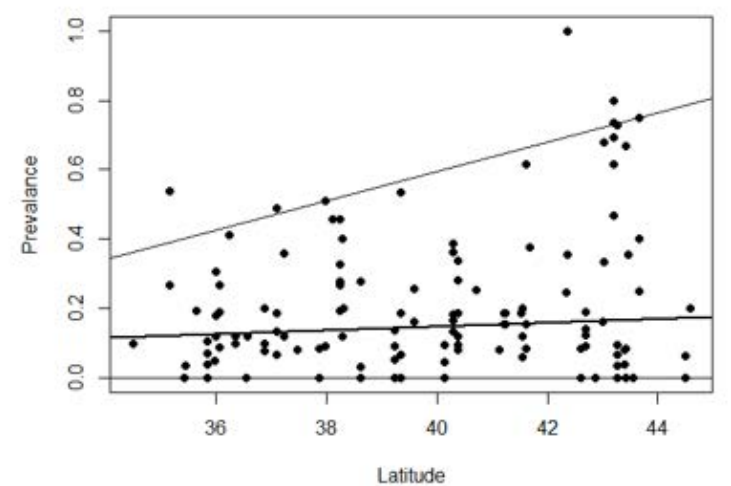

(B)

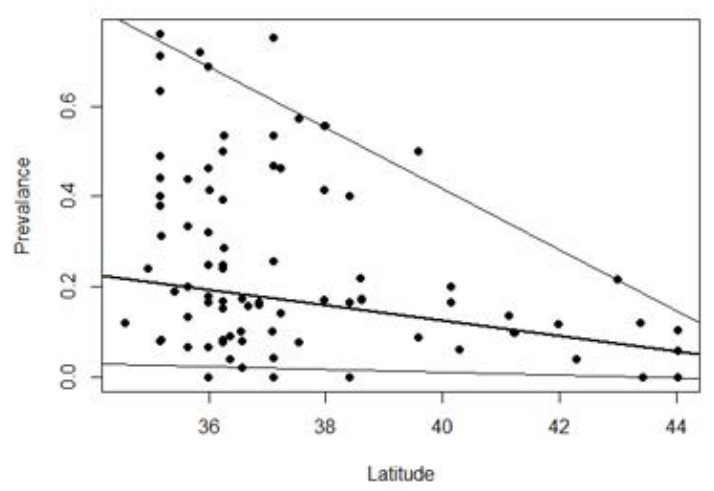

Figure 2. Patterns of weevil prevalence in acorns of (A) Q. rubra and (B) Q. alba across all years of the study. Note that the weevil prevalence increased with latitude in Q. rubra whereas the opposite was true for Q. alba. Statistical analyses en-tailed a percentile regression based on the 2.5, 50 (median) and 97.5 percentiles. For $Q$. rubra, for example, in lower latitudes prevalence is consistently low (between 0 and 35\%) and with progression northward the 97.5 percentile expands as trees show much higher levels of maximal infestation. Note the opposite in Q. alba. Also note that in both species the 2.5 and 50 percentiles are relatively constant across latitude, whereas the 97.5 percentile changes significant but in opposite directions for the two species. $95 \%$ confidence intervals are defined by the two lighter lines whereas the darker line in the middle represents the median.

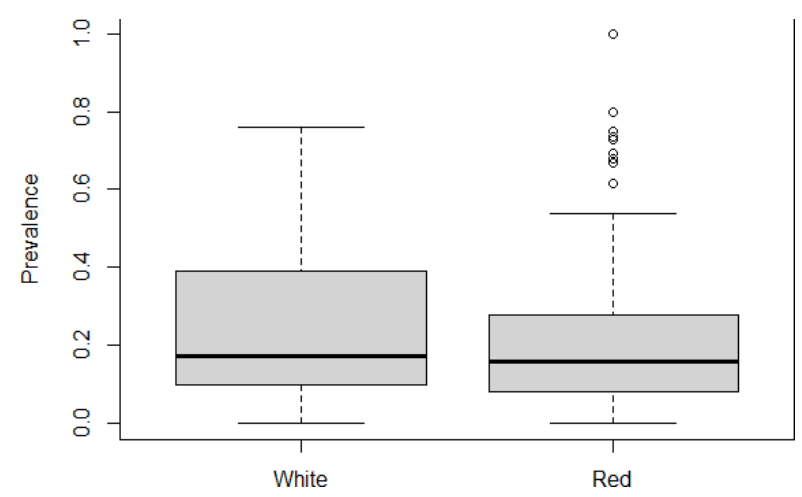

Figure 3. Box plots of weevil infestation prevalence per tree for acorns of both Q. alba and Q. rubra. No significant difference in weevil prevalence was detected for the two tree species (see Results). However, note that the few trees with highest levels of infestation were Q. rubra. 
There was no significant difference in prevalence between northern and southern trees for Q. rubra $(\mathrm{W}=4617, p$-value $=0.9049$, Figure $4 \mathrm{~A})$. However, in $Q$. alba, prevalence was significantly higher $(W=640, p$-value $=0.00006$, Figure $4 B)$ in southern trees $($ mean $(\mathrm{sd})=0.2(0.184)$ than northern trees (mean $0.096(\mathrm{sd}=0.12)$.

In Q. rubra, year had a significant effect on prevalence $(\mathrm{F}=3.94, \mathrm{df}=7,178, p=0.0005)$ but there was no significant interaction between year and latitude $(\mathrm{F}=1.24, \mathrm{df}=7,178$, $p=0.281)$. In $Q$. alba, neither year $(\mathrm{F}=0.655, \mathrm{df}=7,132,0.710)$ nor the year $\mathrm{x}$ latitude interaction $(\mathrm{F}=0.458 \mathrm{df}=7,132, p=0.863)$ were statistically significant. These results and the graphs of prevalence by latitude (Figure 5 ) both suggest that prevalence in Q. rubra is more variable across years than Q. alba.

\subsection{Seed Size across a Latitudinal Gradient}

Q. rubra acorn size significantly decreased with latitude $(p<0.0001)$; however, the effect of latitude was not significant when accounting for the effect of the tree $(p=0.116)$.

Q. alba acorn size was not significantly related to latitude in either the linear $(p=0.886)$ or mixed models $(p=0.121)$.

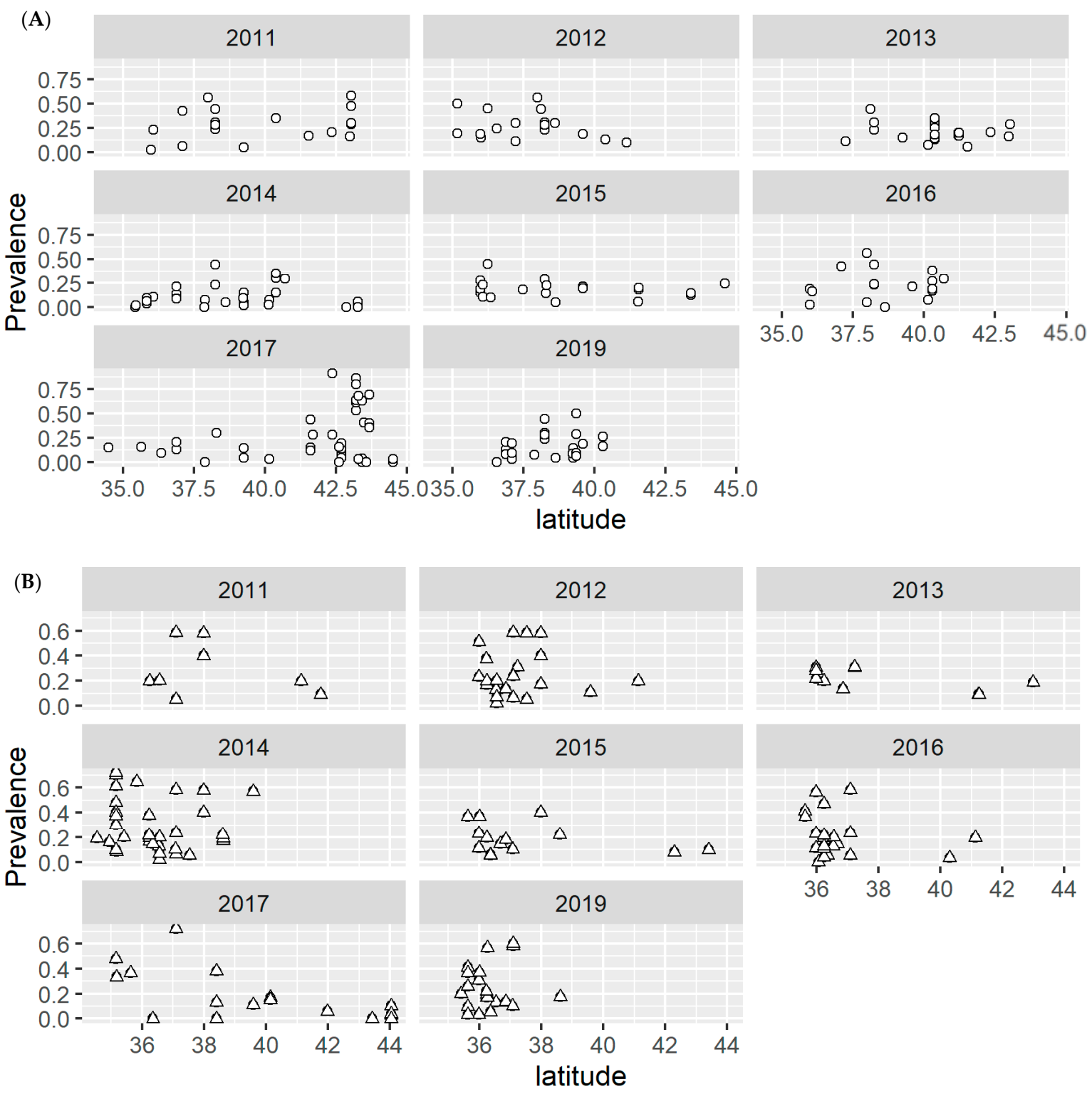

Figure 4. Prevalence by latitude and year for Q. rubra (A) and Q. alba (B). 
(A)

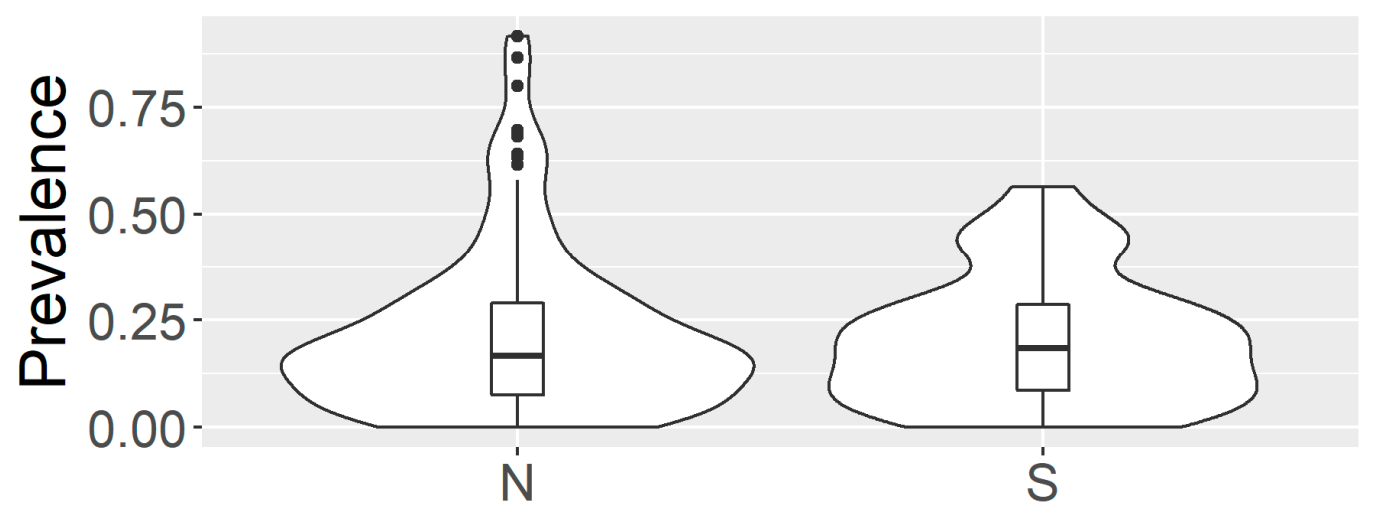

(B)

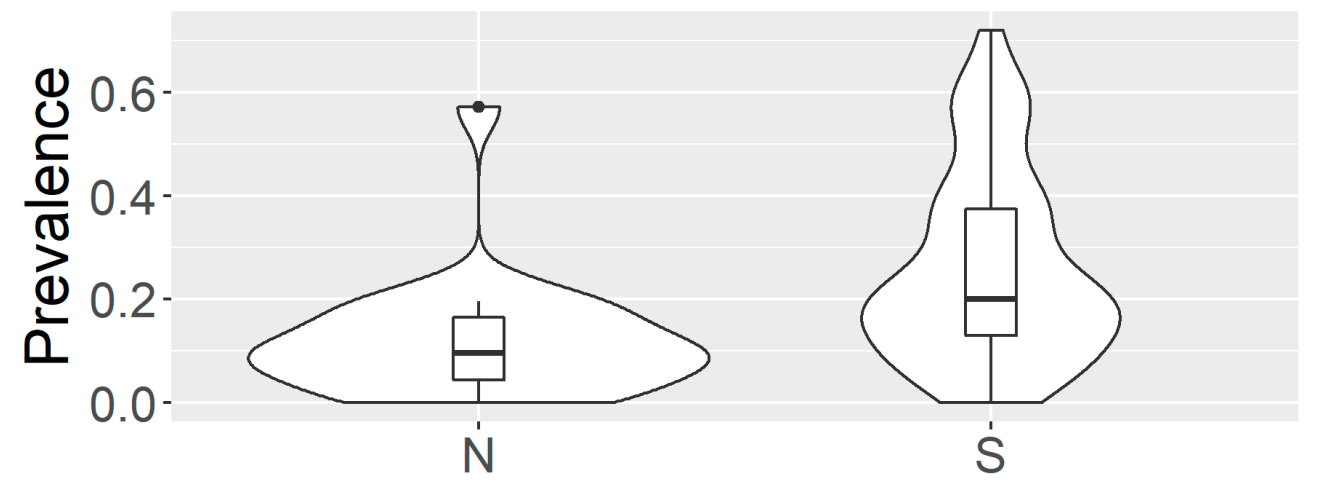

Figure 5. Violin plots showing the distribution of prevalence of acorns in the northern $\left(>39^{\circ}\right)$ and southern $\left(<39^{\circ}\right)$ latitudes for Q. rubra (A) and Q. alba (B) trees. The width of the violin plot indicates the density of the prevalence data. The box indicates the 50th percentile, the line indicates the median, and the whiskers contain the $95 \%$ confidence intervals.

\subsection{Relationship between Cotyledon Damage and Latitude}

Latitude did not have a significant effect on estimates of seed viability in acorns of Q. rubra, although these results were marginally non-significant and slightly higher in lower latitudes for red oak (slope $(\mathrm{SE})=-0.23(0.126)$, nacorns $=618$, ntrees $=83, p=0.067$, Figure 6). This suggests that larger acorn size in lower latitudes may have some advantage with acorn survival in southern latitudes. No such pattern was evident in acorns of Q. alba (slope $(\mathrm{SE})=0.166(0.104)$, nacorns $=394$, ntrees $=62, p=0.112$, Figure 5B). 
(A)

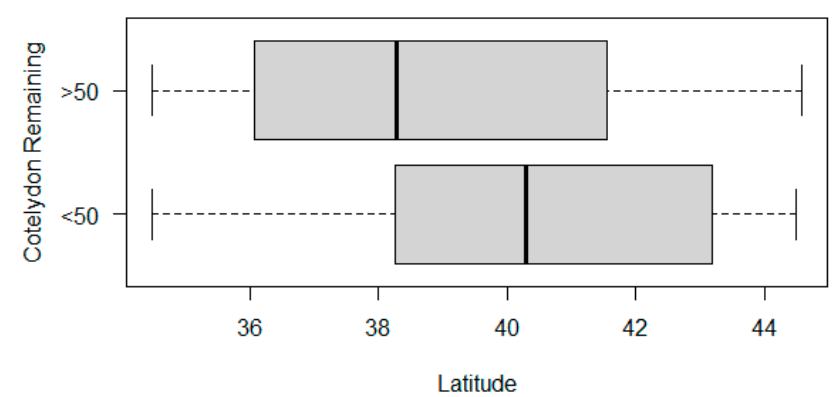

(B)

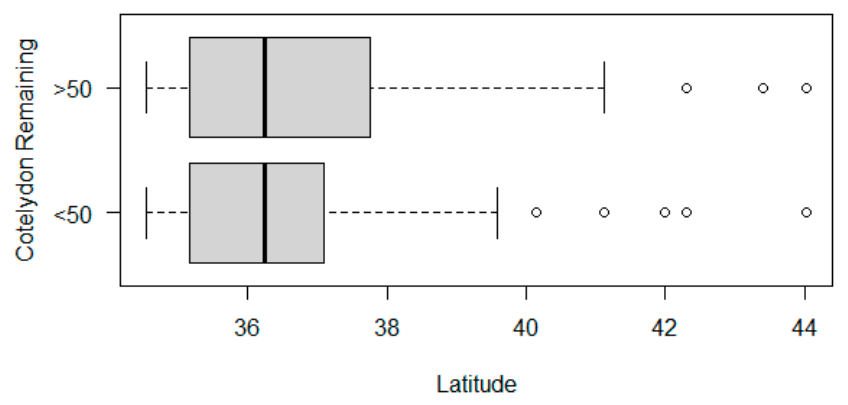

Figure 6. Patterns of cotyledon damage in acorns of (A) Q. rubra and (B) Q. alba across latitude. Shown are the box plots of latitude of acorns with either $>50 \%$ of cotyledon remaining and the same for acorns with $<50 \%$ of cotyledon remaining. Each acorn in this analysis had been infested with only one weevil as evidenced by one exit hole. Q. rubra acorns showed less damage in lower latitudes, however this difference was not significant $(p<0.067)$. Q. alba showed no difference across latitude $(p=0.112)$.

\section{Discussion}

These results represent the first in a series of studies investigating patterns of insect infestation in the acorns of Q. rubra and Q. alba across an extensive latitudinal gradient that covers nearly the entire eastern range of both species (Figure 1). Here, we found that, although overall levels of infestation of nut weevils do not differ between the two species (Figure 3), the 97.5th percentile of the weevil prevalence significantly increased with latitude in $Q$. rubra, while both the median and the 97.5 th percentile decreased with latitude for Q. alba (Figure 2). Given the number of years over which this study was conducted, we argue that these patterns are indeed meaningful and informative. Whether this is due to variation in the frequency of the species of nut weevils specializing in the acorns of Q. rubra and Q. alba in these parts of their range or larger populations of individual species remains to be determined.

These patterns of latitudinal variation in infestation in these two species is further reinforced by long-term patterns of infestation in these two oak species over a 26-year period at one location (northeastern Pennsylvania) in the approximate center of the transects of the present study. As reported by Steele [4], the overall mean prevalence of all insects (primarily nut weevils) per tree ranged from $10 \%$ to $50 \%$ in Q. rubra and $17 \%$ to $50 \%$ in Q. alba. As these data included all insect larvae, it follows that weevil infestation per tree rarely exceeded 30\% during this nearly three decades of monitoring. Likewise, Steele [4] reports on weevil infestation in Q. alba and Q. rubra in 15 individual trees of each species at each of three sites in Pennsylvania over a 19-year period. Mean prevalence $( \pm \mathrm{SD})$ of weevil infestation in Q. alba at each of the three sites was $13.2 \% \pm 10.7,14.6 \pm 15.5$, and $20.4 \% \pm 27.3$. Infestation of $Q$. rubra at the same three corresponding locations was $24.08 \% \pm 18.28,25.9 \% \pm 22.0$ and $37.2 \% \pm 23.7$, respectively.

Results above counter two previous assumptions regarding weevil infestation in acorns of Q. rubra and Q. alba, often advanced in earlier literature. The first is that weevils often destroy $90 \%$ of an acorn crop $([10,25]$ and references therein). It appears that the occasion in which a single tree or an entire crop is heavily infested with weevils is rare and that mean infestation rates per tree rarely exceed $35 \%$, except perhaps in higher latitudes for acorns of Q. rubra and lower latitudes for those of Q. alba. Moreover, it has been suggested higher tannin levels of $Q$. rubra acorns may reduce infestation compared with those of Q. alba [26]. Although tannins are important defense compounds of oaks that influence patterns of insect damage in leaves [27] and, in part, direct weevil damage away from the embryo in acorns [4,17], it is clear that overall weevil infestation of Q. rubra acorns is comparable to that of $Q$. alba acorns. 
Several other factors likely contribute to patterns of nut weevil infestation, including the composition of the weevil community structure in oaks [28], niche specialization and oak species preferences [29], weevil vagility and reproduction [9], length of dormancy during pupal stage, masting patterns in the oaks [30], patterns of forest fragmentation [29], and nutrient supplementation [15], and the disruptive effects of invasive oaks as potential hosts for larval moths and beetles [30,31] However, only the studies by Bogdziewicz et al. $[9,15]$ were conducted in oaks within the range of the present study.

Bogdziewicz et al. [9] relied on a 17-year data set on seed production and patterns of weevil infestation in Q. rubra, Q. alba and Q. montana (chestnut oak; section Quercus), to investigate weevil responses to masting in these oaks. The predator satiation hypothesis predicts that mast crops satiate predators in years of high seed abundance, thus allowing seeds to escape seed predation when seeds are abundant. In contrast, in poor years, the predator-satiation hypothesis predicts populations of seed predators are limited by starvation. While there is strong support for the predator satiation hypothesis when considering the response of rodents and other vertebrates to masting in oaks [32,33], the same does not appear to apply to the response of nut weevils to acorn crops. Bodziewicz et al. [9] found that in three oak forests in northeastern Pennsylvania, masting resulted in a rapid (same-year) bottom-up effect on weevils due to increased reproduction and aggregation on seed rich trees, especially in the two white oak species. However, even in Q. rubra, escape from the effects of insect predation depended on synchronization of mast crops within a population. The overall result, as noted by Steele [4] is a strong positive correlation between acorn numbers and weevil numbers in these oaks. This of course means prevalence is likely to remain stable across years as weevils stay one step ahead of the variation in oak crops. As also shown in Europe, weevils may also be able to thwart the effects of masting by means of prolonged diapause [34,35] which has not been well studied in North America.

The consistent pattern of higher weevil prevalence in the basal end vs. the apical end of the acorn of both Q. rubra and Q. alba suggests that these two oaks may be well prepared to tolerate weevil damage across their entire range. As shown in previous studies, red oak and white oak acorns from northeastern, Pennsylvania exhibit chemical gradients (e.g., tannin, lipid) in which tannin levels are highest in the apical end of the acorn near the embryo and higher lipid levels in the basal end [4,17]. Moreover, in red oaks acorns, $\mathrm{Na}$ is also higher in the basal end of the acorn [4], which is often a limiting nutrient for many herbivores and seed predators [36]. These and other studies also show that these chemical gradients likely direct partial seed predation by both vertebrate and invertebrate seed predators towards the basal end of the seed often allowing these partially damaged acorns to geminate and establish $[4,14,17]$. Results from the present study suggest these defenses may operate across the range of both of Q. rubra and Q. alba, although more data are required on chemical gradients in acorns across latitude.

Acorn size may also play a role in tolerance to partial damage by insect acorn predators. Our observations that Q. rubra acorn size was largest at lower latitudes (except when accounting for tree) is consistent with that of several other studies demonstrating that acorn size in several species decreases with latitude $[34,37]$. Although the likely determinant of such variation in acorn size is often the importance of seed size in dispersal by vertebrates [37,38], but see [39]; increased acorn size may also facilitate tolerance of insect damage as argued by others $[4,6,14]$.

Author Contributions: Conceptualization, M.A.S. and H.J.D.; methodology, M.A.S., H.J.D., S.M., R.C., A.W.B.; validation, M.A.S., H.J.D., S.M., R.C., A.W.B.; formal analysis, J.A.S., H.J.D.; investigation, M.A.S., H.J.D., J.A.S.; resources, M.A.S.; data curation, S.M.; writing —original draft preparation, M.A.S., H.J.D.; writing-review and editing, M.A.S., H.J.D., S.M., A.W.B., R.C., J.A.S.; visualization, M.A.S., H.J.D., J.A.S.; supervision, M.A.S.; project administration, M.A.S., funding acquisition, M.A.S. All authors have read and agreed to the published version of the manuscript. 
Funding: The research was funded by The Wilkes University Research Fund, The Wilkes University Fenner Endowment, The Howard Hughes Medical Institute and the National Science Foundation (DEB-OPUS).

Institutional Review Board Statement: Not applicable.

Informed Consent Statement: Not applicable.

Data Availability Statement: The data presented in this study are available on request from the corresponding author. The data are not publicly available due to ongoing investigation.

Acknowledgments: The authors recognize the contributions of the many Wilkes research students especially Somiah Almeky, Mathew Suchocki, Patrick Lello, Grace Cadigan, Kate Shafer, Kayla Eller and numerous others that assisted in the collection and analysis of acorn samples. MAS also recognizes the financial support of The U.S. National Science Foundation and The Wilkes University Fenner Research Endowment during several years of the study.

Conflicts of Interest: The authors declare no conflict of interest.

\section{References}

1. Nixon, K. The genus Quercus in Mexico. In Biological Diversity of Mexico: Origins and Distribution; Ramamoorthy, T., Bye, R., Lot, A., Fa, J., Eds.; Oxford University Press: Oxford, UK, 1993; pp. 447-458.

2. Nixon, K. Fagaceae. In Flora of North America, North of Mexico; Morin, N.R., Ed.; Oxford University Press: New York, NY, USA, 1997; pp. 436-437.

3. Nixon, K. Global and neotropical distribution and diversity of oak (genus Quercus) and oak forests. In Ecology and Conservation of Neotropical Montane Oak Forests; Caldwell, M., Heldmaier, G., Jackson, R., Lange, O., Mooney, H., Schulze, E., Sommer, U., Eds.; Springer: Berlin, Germany, 2006; Volume 185, pp. 3-13.

4. Steele, M. Oak Seed Dispersal: A Study in Plant-Animal Interaction; Johns Hopkins University Press: Baltimore, MD, USA, 2021; 431p.

5. Fukumoto, H.; Kajimura, H. Effects of asynchronous acorn production by co-occurring Quercus trees on resource utilization by acorn-feeding insects. J. For. Res. 2011, 16, 62-67. [CrossRef]

6. Bogdziewicz, M.; Espelta, J.M.; Bonal, R. Tolerance to seed predation mediated by seed size increases at lower latitudes in a Mediterranean oak. Ann. Bot. 2019, 123, 707-714. [CrossRef]

7. Boucher, D.H.; Sork, V.L. Early drop of nuts in response to insect infestation. Oikos 1979, 33, 440-443. [CrossRef]

8. Bonal, R.; Munoz, A. Seed growth suppression constrains the growth of seed parasites: Premature acorn abscission reduces Curculio elephas larval size. Ecol. Entomol. 2008, 33, 31-36. [CrossRef]

9. Bogdziewicz, M.; Marino, S.A.; Bonal, R.; Zwolak, R.; Steele, M.A. Rapid aggregative and reproductive responses of weevils to masting of North American oaks counteract predator satiation. Ecology 2018, 99, 2575-2582. [CrossRef]

10. Riccardi, C.L.; McCarthy, B.C.; Long, R.P. Oak seed production, weevil (Coleoptera: Curculionidae) populations and predation rates in mixed oak forests of southeast Ohio. In Forest Ecology and Management, General Technical Reports, NE-316, Proceedings of the 14th Central Hardwood Forest Conference, Wooster, OH, USA, 16-19 March 2004; Gen. Tech. Rep. NE-316; Yaussy, D.A., Hix, D.M., Long, R.P., Goebel, P.C., Eds.; U.S. Department of Agriculture, Forest Service, Northeastern Research Station: Newtown Square, PA, USA, 2004; pp. 10-20.

11. Bonal, R.; Espelta, J.M.; Vogler, A.P. Complex selection on life-history traits and the maintenance of variation in exaggerated rostrum length in acorn weevils. Oecologia 2011, 167, 1053-1061. [CrossRef]

12. Bonal, R.; Munoz, A.; Diaz, M. Satiation of predispersal seed predators: The importance of considering both plant and seed levels. Evol. Ecol. 2007, 21, 367-380. [CrossRef]

13. Yi, X.; Yang, Y. Apical thickening of epicarp is responsible for embryo protection in acorns of Quercus variabilis. Isr. J. Ecol. Evol. 2010, 56, 153-164. [CrossRef]

14. Bartlow, A.W.; Agosta, S.J.; Curtis, R.; Yi, X.; Steele, M.A. Acorn size and tolerance to seed predators: The multiple roles of acorns as food for seed predators, fruit for dispersal and fuel for growth. Integr. Zool. 2018, 13, 251-266. [CrossRef]

15. Bogdziewicz, M.; Crone, E.E.; Steele, M.A.; Zwolak, R. Effects of nitrogen deposition on reproduction in a masting tree: Benefits of higher seed production are trumped by negative biotic interactions. J. Ecol. 2017, 105, 310-320. [CrossRef] 
16. Steele, M.; Gavel, K.; Bachman, W. Dispersal of half-eaten acorns by gray squirrels: Effects of physical and chemical seed characteristics. In Ecology and Evolutionary Biology of Tree Squirrels, Proceedings of the International Colloquium on the Ecology of Tree Squirrels, Powdermill Biological Station, Carnegie Museum of Natural History, Pittsburgh, PA, USA, 22-28 April 1994; Steele, M., Merritt, J., Zegers, D., Eds.; Virginia Museum of Natural History: Matinsville, VA, USA, 1998; pp. $223-231$.

17. Steele, M.A.; Knowles, T.; Bridle, K.; Simms, E.L. Tannins and partial consumption of acorns: Implications for dispersal of oaks by seed predators. Am. Midl. Nat. 1993, 130, 229-238. [CrossRef]

18. Hadj-Chikh, L.Z.; Steele, M.A.; Smallwood, P.D. Caching decisions by grey squirrels: A test of the handling time and perishability hypotheses. Anim. Behav. 1996, 52, 941-948. [CrossRef]

19. Bonal, R.; Espelta, J.M.; Munoz, A.; Ortega, J.; Aparicio, J.M.; Gaddis, K.; Sork, V. Diversity in insect seed parasite guilds at large geographical scale: The roles of host specificity and spatial distance. J. Biogeogr. 2016, 43, 1620-1630. [CrossRef]

20. Xia, K.; Harrower, W.L.; Turkington, R.; Tan, H.-Y.; Zhou, Z.-K. Pre-dispersal strategies by Quercus schottkyana to mitigate the effects of weevil infestation of acorns. Sci. Rep. 2016, 6, 37520. [CrossRef] [PubMed]

21. Bogdziewicz, M.; Espelta, J.M.; Muñoz, A.; Aparicio, J.M.; Bonal, R. Effectiveness of predator satiation in masting oaks is negatively affected by conspecific density. Oecologia 2018, 186, 983-993. [CrossRef] [PubMed]

22. Steele, M.A.; Smallwood, P.D.; Spunar, A.; Nelsen, E. The proximate basis of the oak dispersal syndrome: Detection of seed dormancy by rodents. Am. Zool. 2001, 41, 852-864. [CrossRef]

23. Bates, D.; Machler, M.; Bolker, B.; Walker, S. Fitting linear mixed-effects models using Ime4. J. Stat. Softw. 2015, 67, 127003. [CrossRef]

24. R Core Team. R: A Language and Environment for Statistical Computing; R Foundation for Statistical Computing: Vienna, Austria, 2020. Available online: http:/ / www.R-project.org/ (accessed on 12 December 2020).

25. Ricca, M.A.; Weckerly, F.D.; Semlitsch, R.D. Effects of Moisture and Temperature on Overwintering Survival of Curculio Larvae (Coleoptera: Curculionidae). Am. Midl. Nat. 1996, 136, 203-206. [CrossRef]

26. Weckerly, F.W.; Sugg, W.D.; Semlitsch, R.D. Germination success of acorns (Quercus): Insect predation and tannins. Can. J. For. Res. 1989, 19, 811-815. [CrossRef]

27. Schultz, J.C.; Baldwin, I.T. Oak leaf quality declines in response to defoliation by gypsy-moth larvae. Science 1982, 217, 203-206. [CrossRef]

28. Govindan, B.N. The Role of Resource Predictability in the Metapopulation Dynamics of Insects. Ph.D. Thesis, Purdue University, West Lafayette, IN, USA, 2013.

29. Govindan, B.N.; Kery, M.; Swihart, R.K. Host selection and responses to forest fragmentation in acorn weevils: Inferences rom dynamic occupancy models. Oikos 2012, 121, 623-633. [CrossRef]

30. Myczko, Ł.; Dylewski, Ł.; Chrzanowski, A.; Sparks, T.H. Acorns of invasive Northern Red Oak (Quercus rubra) in Europe are larval hosts for moths and beetles. Biol. Invasions 2017, 19, 2419-2425. [CrossRef]

31. Bogdziewicz, M.; Bonal, R.; Espelta, J.M.; Kalemba, E.; Steele, M.A.; Zwolak, R. Invasive oaks escape pre-dispersal insect seed predation and trap enemies in their seeds. Integr. Zool. 2018, 13, 228-237. [CrossRef] [PubMed]

32. Ostfeld, R.S.; Jones, C.G.; Wolff, J.O. Of mice and mast. BioScience 1996, 46, 323-330. [CrossRef]

33. Ostfeld, R.S.; Keesing, F. Pulsed resources and community dynamics of consumers in terrestrial ecosystems. Trends Ecol. Evol. 2000, 15, 232-237. [CrossRef]

34. Menu, F.; Roebuck, J.-P.; Viala, M. Bet hedging diapause strategies in stochastic environments. Am. Nat. 2000, 155, 724-734. [CrossRef] [PubMed]

35. Rajon, E.; Desouhant, E.; Cheavalier, M.; Debias, F.; Menu, F. The evolution of bet hedging in response to local ecological conditions. Am. Nat. 2014, 183, E1-E15. [CrossRef] [PubMed]

36. Weeks, H.P.; Kirkpatrick, C.M. Salt preferences and sodium drive phenology in fox squirrels and woodchucks. J. Mammal. 1978, 59, 531-542. [CrossRef]

37. Aizen, M.A.; Patterson, W.A., III. Acorn size and geographical range in the North American oaks (Quercus L.). J. Biogeogr. 1990, 17, 327-332. [CrossRef]

38. Aizen, M.A.; Woodcock, H. Latitudinal trends in acorn size in eastern North American species of Quercus. Can. J. Bot. 1992, 70, 1218-1222. [CrossRef]

39. Koenig, W.D.; Knops, J.M.; Dickinson, J.L.; Zuckerberg, B. Latitudinal decrease in acorn size in bur oak (Quercus macrocarpa) is due to environmental constraints, not avian dispersal. Botany 2009, 87, 349-356. [CrossRef] 